\title{
$B E$ JUBEL dan $B E$ ANCRUK KULINER EKSTRIM LANGKA di BALI
}

\author{
Dewa Putu Makapagal dan Nelsye Lumanauw \\ Email: dewaputumakapagal@gmail.com dan nel_sye@hotmail.com \\ POLITEKNIK INTERNASIONAL BALI
}

\begin{abstract}
Abstrak
Jubel adalah sejenis larva serangga air berbentuk ulat yang hidup di wilayah perairan berlumpur. Ancruk, berbentuk ulat bulat memanjang berwarna putih, dikenal sebagai ulat sagu. Penelitian ini bertujuan untuk (1) mendeskripsikan gastronomi be jubel dan be ancruk. (2) memeroleh strategi menghindari kepunahan dari sumber hidup bahan utama be jubel dan be ancruk. Penelitian menggunakan teori gastronomi dan teori revitalisasi. Teknik pengumpulan data yang digunakan dalam penelitian ini adalah melalui wawancara dan studi pustaka.

Hasil penelitian menunjukkan bahwa jubel dan ancruk memiliki khasiat yang baik untuk tubuh manusia dengan beberapa kandungan gizinya. tinggi protein (mendukung pertumbuhan dan pemeliharaan jaringan tubuh), bebas dari kolesterol, mengandung asam amino esensial, vitamin, mineral, dan dapat menjaga stamina tubuh agar selalu bugar. Kandungan lemak juga rendah.

Strategi yang dapat dilakukan adalah dengan mereviltalisasi sumber hidup bahan utama be jubel dan be ancruk adalah dengan intervensi fisik dengan membatasi pembangunan pada lahan hijau. Peningkatan kualitas sawah yang masih ada, menerapkan sistem pertanian organik. Sedangkan untuk menyelamatkan ancruk adalah tetap memertahankan keberadaan tanaman yang menjadi habitat hidup ancruk ataupun dengan budi daya.

Kata kunci: jubel, ancruk, langka, Bali.
\end{abstract}

Abstract
Jubel is a caterpillar-shaped water insect larva that lives in muddy waters. Ancruk, in the form of a white elongated caterpillar, is known as a sago caterpillar. This article aims to (1) describe gastronomic beams and features. (2) obtain a strategy of avoiding the extinction of the living resources of jubel and ancruk. The research used gastronomic theory and the theory of revitalization. The data collection techniques used are interviews and literature.

The results of the research show that be jubel and ancruk have good savor for the human body. They are of high protein (supports growth and maintenance of body tissues), free of cholesterol, contain essential amino acids, vitamins, minerals, and can maintain stamina and low fat.

The strategy that can be done is to revitalize the living sources of the main ingredients, such as physical intervention by limiting development in the green zone. Improving the quality of existing rice fields, implementing an organic farming system. Meanwhile, to save ancruk is to maintain the existence of their plants habitat and to do cultivation.

Keywords: jubel, ancruk, rare, Bali. 


\section{Pendahuluan}

Kebiasaan makan tidak hanya sekadar mengatasi kebutuhan tubuh manusia saja, melainkan dapat memainkan peranan penting dan mendasar terhadap ciri-ciri dan hakikat budaya makan. Pola konsumsi, preferensi, dan praktik secara serentak terklasifikasi, yang semuanya merefleksikan dan menggambarkan status/kelas social masyarakat.

Status masyarakat pedesaan kebanyakan adalah kelas menengah ke bawah, biasanya kebanyakan memiliki profesi sebagai petani, juga terkait dengan pola konsumsi, preferensi jenis bahan makanan yang bersumber langsung dari lingkungan pedesaan dan pertaniannya. Maka itu masyarakat pedesaan memiliki kreatifitas memasak bahan-bahan yang diambil juga kebanyakan berasal dari sumber hayati dan alami dari lingkungan pertanian. Di antara preferensi jenis masakan yang kedengaran asing dan terasa ekstrim oleh masyarakat perkotaan mungkin adalah jenis masakan yang dikenal sebagai be jubel dan be ancruk.

Jubel adalah sejenis larva serangga air (kumbang air tawar yang di Bali disebut klipes) berbentuk seperti ulat yang banyak hidup di wilayah perairan berlumpur terutama sawah, danau dan parit di Bali. Punahnya jubel di lingkungan sekitar pertanda tercemarnya dan sakitnya lingkungan tersebut. Karena itu, jubel juga disebut sebagai indikator penentu kebersihan dan kesehatan air, sehingga di mana lingkungan perairannya masih terdapat banyak jubel maka disitu pula terdapat air bersih dan sehat (http://berita.upi.edu/capung-bio-indikator-dari-bangsa-odonata/). Jubel juga banyak membantu petani di sawah karena kemampuannya memburu beberapa hama tanaman dan memangsa jentik-jentik nyamuk yang ada pada air bersih seperti nyamuk malaria (http://programlingkungan.blog spot.co.id/2014/).

Sedangkan ancruk adalah juga sejenis larva serangga kumbang merah bercula (di Bali disebut nyungah) yang biasa hidup di dalam batang pohon 
jaka (pohon nira penghasil sagu) atau pohon kelapa atau pohon dapdap wong dan jenis pohon lainnya yang sudah mati atau ditebang dan membusuk. Ancruk berbentuk ulat bulat memanjang dengan enam kaki mini seperti ulat besar seukuran ibu jari berwarna putih, di beberapa daerah dikenal sebagai ulat sagu, yang nama latinnya adalah Rhynchophorus ferruginesus.

Kedua mahkluk tersebut oleh masyarakat petani di pedesaan di Nusantara, khususnya di Bali ini sering diolah mejadi jenis makanan atau Kuliner Tradisional Bali (KTB) yang mungkin sekarang dianggap sangat ekstrim dan menjijikan. Namun, hasil penelitian mutakhir menunjukkan kedua jenis kuliner dari larva serangga berbentuk ulat ini memiliki kandungan protein dan gizi yang sangat tinggi dan bermanfaat besar bagi tubuh manusia.

Berdasarkan latar belakang masalah di atas maka dapat dirumuskan beberapa masalah berkaitan dengan menu kuliner masa lampau masyarakat Bali dari bahan utama jubel (ulat ranah sawah) dan ancruk (ulat sagu), yaitu: (1) Bagaimanakah gastronomi be jubel dan be ancruk? (2) Bagaimanakan strategi menghindari kepunahan dari sumber hidup bahan utama be jubel dan be ancruk?

\section{Teori dan Metode}

Teori yang digunakan untuk memecahkan pokok permasalahan adalah teori gastronomi merupakan seni atau ilmu terhadap kenikmatan sebuah makanan dan minuman (Scarpato, 2002:36). Teori tersebut digunakan untuk mengkaji kuliner be jubel dan be ancruk. Teori selanjutnya adalah teori revitalisasi, yaitu upaya untuk memvitalkan kembali suatu kawasan yang dulunya pernah vital hidup akan tetapi mengalami kemunduran dan degradasi. Revitalisasi fisik dapat meningkatkan kondisi fisik lingkungan, namun tidak untuk jangka 
panjang. Untuk itu, tetap diperlukan perbaikan dan peningkatan aktivitas ekonomi yang merujuk kepada aspek sosial budaya serta aspek lingkungan.

Penelitian ini memakai pendekatan holistik berarti cara melihat atau memandang sesuatu sebagai suatu kebulatan yang utuh. Penelitian ini bersifat studi pustaka yaitu pengumpulan data dilakukan di perpustakaan Politeknik Internasional Bali, baik melalui buku-buku KTB dan buku-buku manajemen dalam bidang kuliner pariwisata serta ditunjang informasi yang tersedia di internet. Informasi langsung diperoleh dari informan kunci dari generasi lampau yang pernah menikmati dan berpengalaman langsung memasak kuliner ekstrim tersebut.

Jenis penelitian adalah deskriptif analitis (descriptive analitic) yang bertujuan untuk memeroleh secara jelas tentang suatu situasi atau keadaan tertentu yang ada di lapangan melalui pengumpulan data, dalam hal ini khususnya cara membuat kuliner yang sudah langka ini dan kaitannya dengan penyebab terjadinya keterbatasan potensi pasokan bahan alam dan hayati yang ada di daerah Bali saat ini.

\section{Pembahasan}

Pembahasan akan memaparkan jawaban dari masalah yang ada dalam penulisan ini, untuk lebih jelasnya dapat dilihat di bawah ini.

\subsection{Gastronomi Be Jubel dan Be Ancruk}

Gastronomi akan memaparakan secara jelas mengenai be jubel dan be ancruk, mulai dari lokasi, kandungan gizi, sejarah, bahan dan bumbu, cara membuat, cara memasak, hingga cara penyajiannya.

\section{Be Jubel}

Salah satu kuliner tradisional Bali yang sudah sangat langka adalah Be Jubel (lauk jubel) diberi bumbu pedes manis. Masakan jenis ini juga dikenal pada masyarakat luar Bali di sekitar Danau 
Linow, Tomohon, Sulawesi Utara disebut dengan Sayok Pedes. Jenis lauk dari Jubel kini sudah semakin langka akibat berkurangnya populasi jenis ulat tanah sawah ini disebabkan oleh penggunaan bahan beracun atau pestisida dalam perawatan padi di sawah (https://www.boombastis.com/ makanan-dari-serangga/4105).

a) Lingkungan lokasi Be Jubel

Lauk langka yang disebut Be Jubel (Lauk Ulat Tanah Sawah), pada masa lampau masih banyak ditemukan di sekitar pedesaan yang memiliki subak (organisasi lahan pertanian) basah atau sawah yang bersih dari pencemaran lingkungan. Jubel akan banyak berkembang biak setelah pasca tanam padi di sawah basah, dan akan memiliki proses metamorfosis yang cukup panjang. Mulai dari telur serangga yang menempel pada pangkal tanaman padi sawah atau tanaman rumput di tepi parit atau danau, kemudian berkembang menjadi jubel (berbentuk ulat di tanah/sawah) yang hidup pada sarang sedikit di bawah permukaan tanah (tampak seperti ada sembulan kecil di pematang sawah).

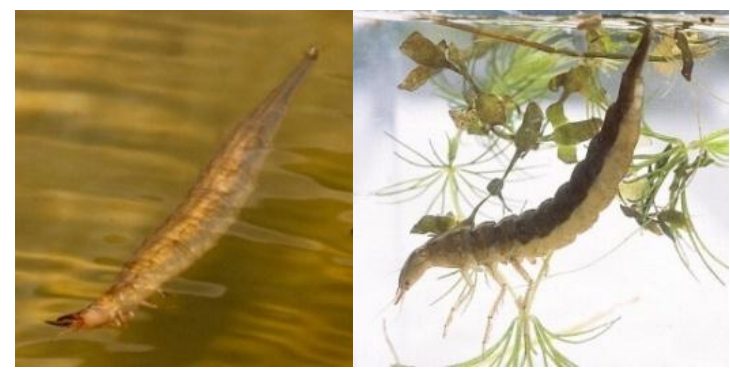

Gambar 1. Cucut atau Jubel yang Masih Muda

Sumber: https://www.google.co.id/search?q= jubel,+kokak+dan+blauk\&hl

Kemudian jubel bermetamorfosis lagi menjadi kumbang air muda di sarangnya yang disebut kokak (sewaktu masih lembek berwarna putih), kemudian berangsur berubah warna menjadi coklat dan mengeras setelah lebih dewasa disebut klipes. 
Waktu senggang pasca tanam padi ini dimanfaatkan oleh para petani untuk menangkap jubel/kokak. Jubel ditangkap waktu masih di sarang yang tampak seperti tanah sedikit menyembul ke atas, yang kalau dicongkel dengan tiga jari tengah tangan kanan (tangan kiri bagi yang kidal) akan terdapat makhluk seperti ulat tanah di dalamnya (warna abu-abu sampai coklat) yang disebut jubel, apabila yang masih muda dan agak ganas suka menggigit namanya cucut (warna coklat lebih cerah).

b) Sejarah Be Jubel

Sejarah be jubel terkait dengan kreatifitas masyarakat petani untuk semaksimal mungkin dapat memanfaatkan lingkungan pertaniannya dalam rangka penghematan biaya dapur keluarga. Terbatasnya keuangan keluarga mendorong masyarakat petani mencari alaternatif lain untuk dapat memenuhi gizi dan protein melalui lauk pauk yaitu mencari dari apa yang dapat dihasilkan oleh lingkungan sekitarnya. Salah satunya yang bersifat musiman adalah musim jubel di sawah.

Kemampuan atau pengetahuan untuk mengolah atau memasak jubel menjadi lauk yang siap dimakan diperoleh atau diwarisi dari leluhurnya secara turun-temurun. Demikian pula dengan variasi cara mengolahan dan memasak serta menyajiannya juga hasil warisan dan sebagian hasil pengembangan kreatifitasnya sendiri. Jadi dikenal berbagai variasi cara memasak be jubel agar bisa menjadi makanan atau lauk yang enak.

c) Kandungan Gizi Be Jubel

Jubel yang merupakan larva serangga kumbang air yang disebut klipes (cybister, mirip serangga kepik dalam ukuran besar di air tawar) ini diduga memiliki kandungan gizi hampir sama dengan ancruk atau ulat sagu (larva dari kumbang merah bercula) yang akan 
di bahas di bawah ini atau jenis serangga sawah lainnya seperti belalang. Nilai kandungan gizi dari serangga belalang misalnya tak boleh dianggap enteng karena tidak kalah dibandingkan sumber protein lainnya seperti daging sapi.

Organisasi Pangan dan Pertanian PBB (FAO) mencatat ada sekitar 1.900 spesies serangga yang aman untuk dikonsumsi manusia. Serangga banyak mengandung serat dan mikronutrisi seperti zat besi atau magnesium. Serangga juga kaya asam lemak yang menghasilkan nutrisi (https://tirto.id/serangga-akan-jadi-penyelamat-krisis-pangancuBH).

Serangga mengandung banyak protein. Selain itu, serangga mengandung berbagai asam amino, vitamin, mineral, asam lemak tak jenuh, dan asam lemak tak jenuh ganda. Kandungan lemak dalam serangga juga rendah. Sebagian besar spesies serangga memiliki kurang dari lima gram lemak per porsi (https://tirto.id/ mau-kudapanbergizi-makan-serangga-saja-codF). Serangga dapat dikonsumsi dalam berbagai jenis masakan. Mulai dari digoreng, direbus, ditumis hingga dipanggang. Terakhir karena rasanya yang lezat. Orang yang mengkonsumsi serangga menggambarkan rasa serangga yang pedas dengan rasa yang mirip dengan udang atau ayam.

d) Bahan dan Bumbu Be Jubel

Untuk membuat be jubel bahan-bahan utama yang perlu disiapkan di antaranya adalah ancruk setengah $\mathrm{kg}$, kelapa satu butir, air bersih secukupnya, dan bahan bumbu berupa basa genep. Bahan dasar bumbu basa genep adalah lengkuas satu potong (seruas jari), kunir satu potong, jahe satu potong, dan kencur satu potong. Bahan pelengkapnya seperti bawang merah 12 siung, bawang putih tujuh siung, cabe rawit lima buah, garam secukupnya, terasi matang empat sendok teh, dan bumbu kuncinya adalah rempah-rempah seperti 
ketumbar dua sendok makan, merica hitam dua sendok makan, merica putih dua sendok makan, kemiri yang sudah disangrai lima butir, daun jeruk lima lembar, serai yang dimemarkan lima batang dipotong-potong kecil. Semua dicampur dan dihaluskan sampai lembi (lembut).

e) Cara Membuat Be Jubel

Bersihkan jubel dari lumpur yang masih melekat dengan air bersih beberapa kali. Jubel direbus sebentar, sudah itu diangkat (waktu merebus jangan lupa diberi perasan air kunir supaya rasa tanah sawahnya hilang), lalu sisihkan. Siapkan kelapa yang telah dibersihkan kulit dagingnya lalu diparut kukur pakai kikian gobed (pemarutan yang lubangnya besar) sehingga hasilnya kelihatan seperti potongan pita pendek tipis-tipis.

f) Cara Memasak Be Jubel

Ambil parutan kelapa dicampur dengan base genep yang telah dihaluskan, lalu dicampur merata dengan menambah air bersih sedikit demi sedikit, sambil diremas-remas sehingga sari kelapa keluar dan bumbu meresap dalam parutan kelapa, lalu masukan ke dalam kuali (penggorengan), dan panaskan. Ambil jubel yang telah direbus lalu dimasukan ke dalam adonan kelapa dan basa genep di atas kuali, tambahkan air sampai semua jubel terendam, selanjutnya didadah (ditumis) di atas api sampai matang, jangan lupa memberi daun salam. Kalau jebelnya sudah kelihatan kempes dan air dadahannya telah mengering itu tandanya sudah matang, biasanya disertai dengan keluarnya aroma harum dari bumbu. Bisa juga waktu mendadah-nya ditambahkan dengan telengis (sari ampas minyak kelapa) agar lebih enak dan manis, lalu ditambahkan potongan cabai rawit, sehingga rasanya menjadi pedas manis. 


\section{g) Cara Penyajian Be Jubel}

Buatkan takir (wadah) dari daun pisang yang dilipat dengan cara khusus dan dijahit dengan semat (lidi kecil atau tusuk gigi dari serat bambu) di kedua ujungnya. Masukan jubel pedes manis yang telah matang secukupnya (untuk satu porsi) di atasnya dan tambahkan bumbu parutan kelapa sebagai penutup di atasnya. Sajikan bersama dengan nasi sela (nasi campur potongan kecil-kecil ketela rambat) ditambah sayur ares dan sambel matah. Rasanya sedap sekali. Inilah sajian khas masyarakat petani pedesaan di masa lampau saat setelah usai musim tanam padi di sawah.

Waktu menyajikan menu be jubel ini akan lebih mantap di sore hari bersama nasi sela dan sambel matah, biasanya disertai minuman tuak hasil sadapan dari pohon kelapa.

\section{Be Ancruk (Ulat Sagu)}

Salah satu makanan harian yang termasuk ekstrim dimiliki beberapa etnik di Indonesia adalah selain dari ulat tanah sawah di atas adalah dari bahan ancruk (ulat sagu) dengan nama latin Rhynchophorus ferruginesus.

\section{a) Lokasi Be Ancruk}

Be Ancruk (lauk ancruk) di Bali pada zaman dahulu sering ditemukan pada lingkungan masyarakat petani yang di wilayahnya masih banyak hutan sagunya (sejenis palem penghasil nira dan sagu) atau pohon kelapanya atau pohon dapdap wong di pegunungan yang banyak dijadikan pelindung pohon kopi. Bila orang memotong pohon sagu untuk dicari sagunya (kandungan isi batangnya), baik untuk kebutuhan konsumsi dijadikan bubur sagu, nasi sagu, atau dipakai pakan ternak (bebek) maka bagian pucuk yang masih muda dibiarkan teronggok begitu saja sampai membusuk, sehingga dimakan oleh 
larva pengurai yang disebut ancruk. Pada saat telah dimakan ancruk ini maka barulah kerak batangnya dibelah untuk menangkap ancruknya, dijadikan lauk.

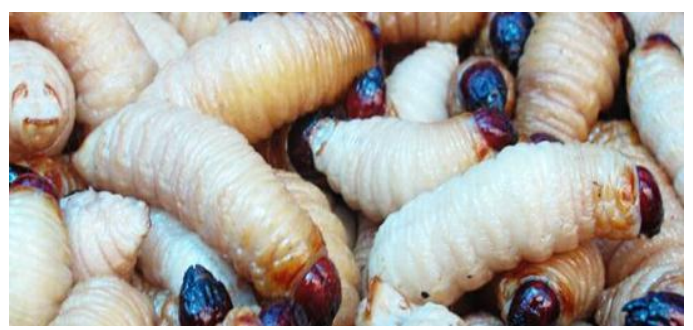

Gambar 2. Kumpulan Ancruk atau Ulat Sagu

Sumber foto: https://backpackerjakarta.com/icip-kuliner-ekstrim-khas-indonesiaberani/

Tetapi bila ancruk ini tidak diambil maka lama-lama sampai bermetamorfosa menjadi kumbang merah dewasa yang disebut nyungah, pada gilirannya bisa menjadi serangga pengganggu (penggerek batang) tanaman khususnya pucuk pohon sagu atau kelapa sehingga pertumbuhannya rusak, pelepah atau daunnya kepotong-potong atau berlubang sejak muda. Cara memeroleh ancruk dengan membelah kerak kulit batang pohon jaka (sagu) tua yang telah lama ditebang serta sudah mengalami proses pembusukan. Ancruk menyukai sagu atau isi/daging dalam potongan batang pohon lain sejenis palem yang telah membusuk sebagai tempat hidup sekaligus menjadi sumber makanannya.

b) Sejarah Be Ancruk

Sejarah lahirnya be ancruk (lauk ulat sagu) tidak bisa lepas dari kebiasaan lingkungan masyarakat agraris. Kebiasaan petani dan lingkungan pertanian melahirkan gagasan untuk berusaha memanfaatkan potensi di alam sekitarnya untuk memenuhi kebutuhan protein dan gizi keluarga. Salah satu potensi alam yang kelihatan ekstrim adalah larva kumbang merah bercula yang disebut ancruk, untuk dijadikan salah satu menu pilihan sebagai bahan lauk 
hariannya. Tujuan dari pembuatan be ancruk adalah agar bisa semaksimal mungkin memanfaatkan potensi lingkungan demi penghematan uang dapur, yang terbatas.

Pada umumnya ancruk yang dikonsumsi tersebut didapat secara alamiah, artinya tidak melalui proses budidaya secara terencana. Watak kreatif masyarakat petani adalah rajin mengamati lingkungan sekitarnya untuk mendapatkan sumber daya yang mungkin bisa dimanfaatkan untuk memenuhi kebutuhan hidupnya. Salah satunya yang mungkin bisa dimanfaatkan adalah adanya sisa pucuk tebangan pohon jaka (sagu) dan pohon kelapa yang telah membusuk. Atau bagi masyarakat Bali di pegunungan yang hidup dari ladang pohon kopi dapat mengamati adanya potongan dahan pohon pelindung kopi yang disebut dapdap wong yang telah membusuk. Ketiga jenis batang tananam tersebut yang sering dimakan oleh larva kumbang merah, yang setelah besar disebut ancruk.

Pada zaman dahulu, lingkungan tumbuh pohon sagu dan kelapa di Bali tidak terbatas hanya di sekitar dataran rendah tetapi juga sampai ke dataran tinggi (pegunungan). Oleha karena itu sebaran lingkungan keberadaan lauk ulat sagu (be ancruk) juga ada di berbagai wilayah topograpi. Namun, kini akibat pertumbuhan kotakota dan padatnya pemukiman di pedesaan maka lingkungan tumbuh pohon sagu dan kelapa sudah mulai terbatas, hanya tinggal di tempattempat yang tidak produktif, seperti sekitar tepi jurang bukit atau sungai di dataran tinggi atau pegunungan. Namun eksistensi pohon dapdap wong yang dijadikan pelindung pohon kopi di daerah dataran tinggi, juga kini mengalami masalah kepunahan yang belum jelas penyebabnya, sehingga populasi ancruk juga semakin berkurang. 


\section{c) Kandungan Gizi Ancruk}

Ulat yang satu ini bisa untuk dikonsumsi karena memiliki khasiat yang baik untuk tubuh manusia dengan beberapa kandungan gizinya. Di setiap 100 gram ancruk (ulat sagu), berdasar hasil penelitian memiliki kandungan sekitar 9,34 persen protein. Angka ini jauh lebih tinggi dari protein telur ayam. Ancruk juga bebas dari kolesterol sehingga sangat baik untuk kesehatan tubuh. Beberapa kandungan lain ancruk berdasarkan klasifikasi tabel gizi, terdapat kandungan asam amino esensial, seperti asam aspartat (1,84\%), asam glutamat $(2,72 \%)$, tirosin $(1,87 \%)$, lisin $(1,97 \%)$, dan methionin $(1,07 \%)$.

Selain itu, konon ulat sagu juga dipercaya masyarakat Maluku dan Irian dapat menjaga stamina tubuh agar selalu tetap tinggi dalam melakukan rutinitas sehari-hari (https://ww w.kaskus.co.id/thread/ 56bbfbd4507410c44d8b456a/ulat-sagu-kuli ner-ekstrim-tapi-kayagizi/).

Berdasarkan penelitian Istalaksana (2013) dari Jurusan Teknologi Pertanian Universitas Negeri Papua, ulat sagu terutama mengandung lemak dan protein, sehingga dapat dijadikan sumber lemak dan protein yang baik bagi bahan pangan. Kandungan tertinggi adalah asam kaprat (asam lemak rantai menengah) dan asam oleat (asam lemak tak jenuh). Hal tersebut menunjukkan bahwa lipid ancruk adalah sumber lemak yang baik bagi bahan pangan. Kandungan proteinnya cukup tinggi, yaitu dengan rata-rata 32,54\%. Kandungan protein yang tinggi dalam ancruk (ulat sagu) nantinya akan digunakan untuk membentuk protein struktural yang diperlukan dalam pembentukan jaringan tubuh larva.

Sedangkan penelitian Purnamasari (2010) dari Jurusan Biologi Universitas Cenderawasih Papua, menemukan bahwa ransum yang mengandung ulat sagu mempunyai kualitas yang hampir manyamai 
protein standar (kasein), yang berarti protein ulat sagu dapat dimanfaatkan dalam mendukung pertumbuhan dan pemeliharaan jaringan tubuh. Nilai kimianya cukup tinggi, hal ini disebabkan karena jumlah dan jenis asam amino esensial yang menyusun protein ulat sagu sesuai dengan jumlah dan jenis asam amino esensial dalam pola referensi FAO (1973). Hal ini berarti jenis dan jumlah asam amino esensial dalam protein ulat sagu dapat mencukupi kebutuhan tubuh untuk membentuk protein yang diperlukan bagi pertumbuhan dan pemeliharaan tubuh (http://www.tribunnews.com/tribunners/ 2016/05/20/ulat-sagu-kuliner-unik-kaya-lemak-dan-protein).

d) Bahan dan Bumbu Be Ancruk

Untuk membuat timbungan ancruk bahan-bahan yang perlu disiapkan diantaranya adalah: a) Ancruk setengah kg, b) Batang bambu muda yang sudah dipotong-potong dengan panjang seruas (setengah meter) disiapkan sebagai wadah pembakaran (timbung), c) Daun pisang yang menjadi alas adonan dan penyumpal juga ikut disediakan atau dapat diganti dengan daun bambu, d) Sabut kelapa kering untuk media api pembakaran.

Untuk bumbu timbungan ancruk setengah kg diperlukan bahanbahan basa genep sebagai berikut: lengkuas/laos satu potong (seruas jari), kunir satu potong, jahe satu potong, bangle satu potong dan kencur satu potong. Bahan pelengkapnya seperti bawang merah 12 siung, bawang puth tujuh siung, cabe rawit lima buah, garam secukupnya, terasi matangempat sendok teh, dan kuncinya adalah rempah-rempah seperti ketumbar/lada dua sendok teh, merica hitam dua sendok teh, merinca putih dua sendok teh, kemiri yang sudah disangrai lima butir, daun jeruk lima lembar, jinten, gula merah, dan semua dirajang halus atau dicampur dan dihaluskan sampai lembi (lembut). 


\section{e) Cara Membuat Be Ancruk}

Ancruk bisa dijadikan masakan biasanya dengan cara dibumbui, paling sederhana bisa dengan teknik dibakar atau direbus lebih dahulu (http://akarumput.com/featured/searching-for-bali\%E2\%80 \%99sforgotten-foods/). Pada umumnya masyarakat asli Papua juga sering memasak ancruk dengan dicampur ke dalam masakan seperti tumisan sayur atau langsung digoreng untuk dihidangkan dengan sambal. Namun, kadangkala ada beberapa warga wasyarakat Papua yang biasa menyantap Si Ulat Sagu ini langsung dalam keadaan hidup setelah mendapatkannya dari pohon sagu yang sudah lama ditebang tersebut. Hal ini yang membuatnya terlihat sangat ekstrim dan menjijikkan, karena ulat sagu langsung disantap mentah-mentah.

Rasa ulat sagu relatif, tapi bagi yang sering memakannya selalu mengatakan enak dan gurih. Alasannya karena memang terasa gurih di lidah, didukung oleh teksturnya yang lunak, juga sedikit asin. Di beberapa tempat atau dalam suatu kesempatan lain ulat ini bisa dibuat sate atau dibakar setelah itu ditambah dengan bumbu sambal balado. Dalam perkembangannya, ada salah satu anak bangsa yang berasal dari tanah Papua, yaitu Mike Toam, pernah berinovasi memilih ulat sagu sebagai objek penelitiannya untuk Konferensi Internasional Peneliti Muda di Nijmegen, Belanda, pada pertengahan April 2012 yang lalu. Mike secara kreatif mengolah ulat sagu menjadi berbagai jenis makanan yang digemari masyarakat, seperti bakso, spaghetti, nasi goreng, sandwich, dan keripik, demi menghilangkan kesan geli dan menjijikkan yang kerap melekat pada serangga gendut putih ini. Penelitian tersebut pun berhasil membuat Mike meraih medali perunggu (https://senja moktika.wordpress.com/2015/10/18/ulatsagu-si-gendut-putih-yang-sudah-sampai-belanda/). 
Cara membuat timbungan ancruk yang umum di Bali adalah: (a) Ancruk ditambah basa rajang atau basa genep ditambah minyak kelapa ditambah garam dan daun salam yang dipotong-potong tipis ditambah bumbu serbuk. (b) Diaduk dan dilumat sampai rata ditambah air panas (sekedar kena). (c) Masukkan adonan ke dalam ruas bumbung bambu yang masih mentah atau segar (tidak kering) lalu tutup rapat dengan potongan kayu atau disumpal dengan gulungan daun pisang atau daun bambu segar, untuk siap dibakar (dikedusin). (d) Cara lain mengolahnya adalah: Setelah habis menyiapkan bumbu, mulai digelar potongan lembaran kecil daun pisang di atas meja. Guna lembaran daun pisang itu adalah sebagai media wadah ancruk agar siap dipepes dalam batang bambu (timbungan). Di atas daun pisang diisi bumbu lima sendok makan. Ancruk yang gendut dan masih hidup lalu dibaringkan dan dibenamkan di dalamnya. Kemudian disiram air perasan jeruk lemo, kemudian bungkus dengan melipat daun pisangnya. Lalu ancruk yang telah dibungkus dengan daun pisang yang berisi bumbu itu kemudian dimasukkan ke dalam lubang bambu yang telah dibersihkan. Permukaan corobong bambu yang terbuka disumpal rapat juga dengan lipatan daun pisang atau daun bambu (https://ww w.balipuspanews.com/ancruk-larfa-kumbang-jadi-masakan-bercita rasa-tinggi.html).

\section{f) Cara Memasak Timbung Ancruk}

Lubang potongan batang bambu sepanjang kurang lebih $50 \mathrm{~cm}$ yang telah diisi adonan ancruk beserta "base genep" yang sudah dihaluskan kemudian disumbat corobongnya rapat-rapat (https://ww w.balipuspanews.com/ancruk-larfa-kumbang-jadi-masakan-bercita rasa-tinggi.html). Batang-batang bambu itu lalu direbahkan ke dalam bara api yang berasal dari pembakaran sabut kelapa. Hanya berjarak 
sekitar sepuluh menit, bau harum bumbu timbungan ancruk itu sudah mulai tercium, sebagai tanda proses pematangan. Masakan yang sudah betul-betul matang ditandai dengan air yang berhenti menetes dari dalam lubang bambunya. Sekitar 30 menit timbungan ancruk dalam bambu biasanya sudah benar-benar matang. Lalu diangkat dan dibuka tutup bambunya untuk dikeluarkan isinya untuk siap disajikan.

\section{g) Cara Menyajikan Timbung Ancruk}

Timbungan ancruk yang telah matang, yang dibuat seperti membungkus pepes disajikan dengan cara tinggal membuka daun pepesnya setelah dikeluarkan dari bambu, lalu dihidangkan di atas piring. Tapi kalau tidak dibuat dengan cara dibungkus daun (pepes), tinggal tambahkan potongan daun pisang di atas piring, lalu sajikan timbungan ancruk yang telah dikeluarkan dari dalam bambu di atasnya. Rasanya mirip udang tapi lebih tebal.

Waktu menyajikan menu timbungan ancruk ini akan lebih mantap di sore hari bersama nasi sela dan sambel matah, biasanya disertai minuman tuak hasil sadapan dari pohon kelapa.

\subsection{Strategi Menghindari Kepunahan Dari Sumber Hidup Bahan Utama Be Jubel Dan Be Ancruk}

Strategi yang dapat dilakukan adalah dengan mereviltalisasi sumber hidup bahan utama be jubel dan be ancruk adalah dengan intervensi fisik dengan membatasi pembangunan pada lahan hijau. Perbaikan dan peningkatan kualitas dan kondisi fisik sawah yang masih ada. Pembatasan penggunaan bahan-bahan kimia yang dapat merusak alam hidup jubel dan ancruk. Pembangunan tetap bisa dilakukan akan tetapi tetap harus memperhatikan konteks lingkungan, khususnya lingkungan sawah yang merupakan habitat utama bagi jubel dan ancruk. 
Selain dengan intervensi fisik, dapat dilakukan dengan budidaya adalah "usaha yang bermanfaat dan memberi hasil" (https://id.wikipedia. org/wiki/Budi_daya). Pembudidayaan merupakan salah satu strategi paling ampuh dalam menghindari kepunahan dari sumber hidup bahan utama be jubel dan be ancruk. Sayangnya jubel tidak bisa dibudidayakan karena lingkungan kehidupannya sangat alami di dalam tanah sawah. Bahkan kini jubel telah mengalami ambang kepunahan, akibat pemakaian pestisida dalam pengelolaan sistem pertanian sawah.

Pembudidayaan hanya dapat dilakukan pada ancruk. Mengingat lingkungan tumbuhnya ancruk adalah di dalam batang pohon yang telah membusuk, maka jika ingin membudidayakan ancruk seseorang harus menebang pohon jaka (sagu/nira) atau pohon kelapa atau pohon dapdap wong terlebih dulu, lalu didiamkan beberapa minggu atau bulan sampai pohon tersebut membusuk. Ancruk ini hidup di batang sagu yang membusuk. Membusuknya batang pohon akan memancing kedatangan kawanan kumbang merah untuk bertelur di sana. Setelah semakin lama membusuk, maka ulat di dalamnya akan semakin gendut. Setelah tumbuh menjadi larva dewasa (ulat putih gendut) barulah kerak batang pohon sagu dibelah sampai ketemu ulat sagunya untuk dikumpulkan.

\section{Penutup}

Be jubel lalah manis dan timbungan be ancruk mungkin dapat dikatakan sebagai salah satu kuliner ekstrim yang sering dikonsumsi oleh masyarakat petani pedesaan di Bali di masa lampau. Namun sejalan dengan perkembangan waktu dan perubahan lingkungan social dan alam menyebabkan semakin langkanya sumber daya hayati dari jenis kuliner ini. Namun untuk menyelamatkan jenis kuliner tradisi ini perlu sekali diadakan semacam dokumentasi resep dan praktek dalam bentuk lomba memasak kuliner langka setempat. 
Mengapresiasi kuliner lokal dengan memasak di dapur sendiri, menjadi langkah paling nyata dalam melestarikan budaya Kuliner Tradisional Bali (KTB). Dengan apresiasi yang berbasis dari rumah, dari dapur sendiri, masakan lokal akan menjadi tuan rumah di negeri sendiri. Untuk itu agar kuliner nusantara khususnya KTB tidak punah, memang harus ada standarisasi proses pengolahan dalam bentuk resep. Standarisasi resep itu penting kalau tidak kehilangan cita rasa khas tradisi setempat di masa mendatang. Dan kalau masakan tradisional daerah sudah mulai kehilangan standarnya, lama lama akan bisa kehilangan rasa unggulnya.

Sangat penting bagi pemerintah daerah untuk melaksanakan banyak event KTB yang sudah langka. Pelaksanaan event-event KTB ini bertujuan untuk mengeksplorasi sebanyak mungkin kekuatan kuliner nusantara khususnya Bali sebelum memasuki kepunahannya, dengan harapan KTB dapat bertahan dan terus dilestarikan.

\section{Daftar Pustaka}

Ariani, Risa Panti. 2017. Mengenal Kuliner Bali. (Ed.1, Cet.1.). Depok: Rajawali Pers.

Kusumawati, Rika, Putra, Winkanda Satria. 2013. Resep Masakan Nusantara Favorit dari Aceh Hingga Papua. Yogyakarta: C.V. Andi Offset.

Pitanatri, Putu Diah Sastri, Putra, I Nyoman Darma. 2016. Wisata Kuliner Atribut Baru Destinasi Ubud. Denpasar: Jagatpress bekerja sama dengan Program Studi Magister Kajian Pariwisata Universitas Udayana.

Remen, I Ketut. 1987. Olah-olahan Paebatan Bali. Tanpa penerbit.

Scarpato, Rosario. 2002. "Gastronomy Studies in search of Hospitality" Journal of Hospitality and Tourism Management, Vol. 9 (2): 1-36.

Surayin, Ida Ayu. 2007. Masakan Bali. Surabaya: Paramita.

Wrasiati, Luh Putu, Wijaya, I Made Anom Sutrisna, Suter, I Ketut, Wiranatha, A.A. Putu Suryawan. 2017. Kuliner Tradisional Bali (Balinese Traditional Kulinary). Denpasar: Udayana University Press.

\section{Informan:}

1. Nama : I Wayan Sabeh

Alamat : Lingkungan Tengah, Desa Adat Lukluk, Mengwi, Badung, Bali

Umur $\quad: 78$ tahun 
2. Nama : Made Kesiar

Alamat : Lingkungan Badung, Desa Adat Lukluk, Mengwi, Badung, Bali

Umur : $\quad: 76$ tahun

3. Nama : Ni Nyoman Pineh

Alamat : Lingkungan Badung, Desa Adat Lukluk, Mengwi, Badung, Bali

Umur : $\quad$ : 70 tahun

4. Nama : Wayan Kariawan

Alamat : Lingkungan Badung, Desa Adat Lukluk, Mengwi, Badung, Bali

Umur : 54 tahun

\section{Studi Internet:}

Anonim. 2014. Mengolah Sampah adalah Ibadah. (serial online). [cited 2017 Oct. 2]. Available from URL: http://programlingkungan. blogspot.co.id/ 2014/.

Anonim. 2016. Invertebrata. (serial online). [cited 2017 Oct. 2]. Available from URL: https://royalalbertamuseum.ca/research/lifeSciences/invertebrate Zoology/bugsfaq/diving.htm.

Anonim. 2016. Ulat Sagu, Kuliner 'Ekstrim' tapi Kaya Gizi. (serial online). [cited 2017 Oct. 2]. Available from URL: https://www.kaskus.co.id/ thread/56bbfbd4507410c44d8b456a/ulat-sagu-kuliner-ekstrim-tapikaya-gizi/.

Anonim. 2017. “Ancruk" Larva Kumbang Jadi Masakan Bercitarasa Tinggi. (serial online). [cited 2017 Oct. 2]. Available from URL: https://www. balipuspanews.com/ancruk-larfa-kumbang-jadi-masakan-bercitarasatinggi.html.

Djordy, Fransiscus. 2016. 5 Makanan Ekstrem Yang Lazim Di Indonesia, Lu Wajib Ngerasain Gengs! (serial online). [cited 2017 Oct. 2]. Available from URL: https://dagelan.co/5-makanan-ekstrem-yang-lazim-di-indo nesia-lu-wajib-ngerasain-gengs.

Fateta, Jendral. 2012. Kandungan Gizi Belalang Sebagai Makanan. (serial online). [cited 2017 Oct. 2]. Available from URL: http://fateta.ipb.ac.id/ kandungan-gizi-belalang-sebagai-makanan/.

Guswati, Hilal. 2016. Icip Kuliner Ekstrim Khas Indonesia, Berani? (serial online). [cited 2017 Oct. 2]. Available from URL: https://backpacker jakarta.com/icip-kuliner-ekstrim-khas-indonesia-berani/.

Miyanti. 2015. Capung, Bio-Indikator Dari Bangsa Odonata. (serial online). [cited 2017 Oct. 2]. Available from URL: http://berita.upi.edu/capung-bioindikator-dari-bangsa-odonata/.

Mustafa, Ardita. 2017. Pepes Ulat Sabeta, Kuliner Khas dari Jailolo. (serial online). [cited 2017 Oct. 2]. Available from URL: https://www.cnnindo nesia.com/gaya-hidup/20170505211402-262-295994/pepes-ulat-sabetakuliner-khas-dari-jailolo.

Muthia, Husna. 2016. Ulat Sagu Kuliner Unik Kaya Lemak dan Protein. (serial online). [cited 2017 Oct. 2]. Available from URL: http://www.tribun 
news.com/tribunners/2016/05/20/ulat-sagu-kuliner-unik-kaya-lemakdan-protein.

Pasifico, Alfred. 2011. Mencari Masakan Bali Yang Nyaris Punah. (serial online). [cited 2017 Oct. 2]. Available from URL: http://akar umput.com/featured/searching-for-bali\%E2\%80\%99s-forgotten-foods/

Sefin. 2015. Ulat Sagu: Si Gendut Putih yang Sudah Sampai Belanda. (serial online). [cited 2017 Oct. 2]. Available from URL: https://senjamoktika. word press.com/2015/10/18/ulat-sagu-si-gendut-putih-yang-sudahsampai-belanda/comment-page-1/.

Takuler, Spec. 2017. Mencari Ulat Sagu. (serial online). [cited 2017 Oct. 2]. Available from URL: https://www.youtube.com/watch?v=LJMuasce 1 po.

\section{Profil Penulis}

Dewa Putu Makapagal, SE.,MM.,CHA lahir di Yeh Embang, 24 Mei 1964. Menempuh pendidikan Diploma Balai Pendidikan dan Latihan Pariwisata (BPLP) Nusa Dua dan tamat pada 18 Juni 1985. Program Sarjana diselesaikan tahun 2005 di Sekolah Tinggi Ilmu Manajemen Indonesia (STIMI) "Handayani" Denpasar. Pendidikan Magester ditempuh di Sekolah Tinggi Ilmu Ekonomi (STIE) "TriatmaMulya" tahun 2010. memiliki pengalaman mengajar Mata Kuliah Hotel Operation Analysis dan Total Quality Management for Hospitality Industry. Saat ini menjadi General Manager Hotel \& Villas serta Dosen Seni Kuliner di Politeknik Internasional Bali, khususnya mata kuliah Akuntansi untuk Kuliner.

Nelsye Lumanauw, SE.,M.Par menyelesaikan Pendidikan Sekolah Dasar hingga SMA di Magelang. Menamatkan Sarjana Ekonomi Manajemen di Universitas Ngurah Rai Denpasar pada tahun 2012. Pendidikan Magister di bidang Pariwisata Universitas Udayana Denpasar diselesaikan tahun 2015. Saat ini menjabat menjadi Dosen D3 Seni Kuliner di Politeknik Internasional Bali. 